SAINS TANAH - Journal of Soil Science and Agroclimatology

Journal homepage: http://jurnal.uns.ac.id/tanah

\title{
Analysis of drought hazards in agricultural land in Pacitan Regency, Indonesia
}

\author{
Istika Nita ${ }^{1 *}$, Aditya Nugraha Putra ${ }^{1}$, Alia Fibrianingtyas ${ }^{2}$ \\ ${ }^{1}$ Department of Soil Science, Faculty of Agriculture, Brawijaya University, Malang, East Java, Indonesia \\ ${ }^{2}$ Department of Socio-Economic Agriculture, Faculty of Agriculture, Brawijaya University, Malang, East Java, Indonesia
}

\begin{tabular}{|c|c|}
\hline ARTICLE INFO & ABSTRACT \\
\hline $\begin{array}{l}\text { Keywords: } \\
\text { Drought } \\
\text { Pacitan } \\
\text { Disasters } \\
\text { Agriculture } \\
\text { Land use } \\
\text { Article history } \\
\text { Submitted: 2019-11-19 } \\
\text { Accepted: 2020-04-21 } \\
\\
\text { * Corresponding Author } \\
\text { Email address: } \\
\text { istika.nita@ub.ac.id }\end{array}$ & $\begin{array}{l}\text { Pacitan Regency is a region in East Java Province with varied landforms and high disaster } \\
\text { potential, including drought. The drought hazard in this region has not yet been } \\
\text { determined. This study was conducted to analyze the potential of drought in Pacitan } \\
\text { Regency in } 2018 \text { with the previous two decades (1998 and 2008) to predict future } \\
\text { droughts. The study also focused on verifying how land-use changes impact drought } \\
\text { potential. Mapping drought potential was based on the Ministry of Forestry method and } \\
\text { was modified for this study. Drought potential was determined by scoring features and } \\
\text { analyzing with a weighted overlay. Reference parameters and patterns of land-use change, } \\
\text { as determined by Landsat 5, 7, and } 8 \text { satellite imagery, were analyzed. Then, the changing } \\
\text { pattern was used to predict future } 2030 \text { land-use patterns using business as usual (BAU) } \\
\text { analysis. For comparison, a land-use analysis was also done using the land capability class } \\
\text { (LCC) and regional spatial plan (RSP). Data was validated using a confusion matrix. The } \\
\text { accuracy of the drought estimation for Pacitan Regency was } 75 \% \text {. The results showed that } \\
\text { the drought potential high and very-high level risk groups increased. The increase occurred } \\
\text { due to changes in land use, specifically land management and plant species selection. } \\
\text { Based on the results of the predicting BAU analysis, the level of potential of drought will } \\
\text { increase by } 2030 \text {. The regional spatial plan (RSP) and LCC analysis determined that, with } \\
\text { no drought intervention, drought hazard in Pacitan Regency will increase. }\end{array}$ \\
\hline
\end{tabular}

How to Cite: Nita, I., Putra, A. N., and Fibrianingtyas, A. (2020). Analysis of drought hazards in agricultural land in Pacitan Regency, Indonesia. Sains Tanah Journal of Soil Science and Agroclimatology, 17(1): 7-16 (doi: 10.20961/stjssa.v17i1.35688)

\section{Introduction}

Drought impacts many things, including the decline in agricultural land productivity. Drought is a natural phenomenon that dramatically affects crop growth and production (Hamidi \& Safarnejad, 2010). When the supply of water in the soil reaches an absolute pressure that prevents plants from absorbing it, plant photosynthesis is disrupted (Zhang et al., 2015). In the Pacitan districts, landforms vary but are dominated by karst, a contributing factor to the region's drought susceptibility. According to BNPB data from 2017 to early 2018, there were three droughts in Pacitan Regency between 2011 and 2018. There are 94,438 ha of agricultural land in the Regency, 40,999 ha of which is paddy land (BPS-Kabupaten Pacitan, 2018) and could potentially experience crop failure. Therefore, drought relief efforts are needed.

The potential of this region is not only derived from tourism, but also agriculture; a variety of agricultural commodities are produced there. Pacitan Regency consists of 12.015 ha of paddy fields, 129.972 ha of dry land, and 34.662 ha of agroforestry (BPS-Kabupaten Pacitan, 2018). However, the potentials of these land uses are limited by natural disasters, particularly landslides, floods, and droughts. Based on BNPB data from 2017 to early 2018, there were nine landslides and four floods from 2017 to early 2018 and three droughts between 2011 and 2018 in Pacitan Regency. Although the number of drought events was lower than landslides and floods, the effected drought areas were vast (49 out of 171 villages and sub-districts, or around $28 \%$, were affected by drought) and effected nearly year-round.

Drought impacts various fields, including agriculture. Venuprasad, Lafitte, \& Atlin (2007) suggested that drought was the leading cause of the decline in rice production, which affected 40 million hectares in Asia. The insufficient water supply associated with droughts decreases agricultural production. The long dry season in Indonesia is the leading cause of drought in Pacitan Regency and other regions. D'Arrigo \& Wilson (2008) stated that droughts are caused by El Nino events in the Tropical Pacific Ocean. Over 350 ha of 
paddy fields were damaged by drought in Pacitan Regency (BPS-Kabupaten Pacitan, 2018), resulting in crop failure and decreased paddy production.

Drought disaster management efforts must be carried out in an integrated manner and involve a variety of stakeholders, including both government and other (Azadi et al., 2018). Collaboration among stakeholders was expected to produce a variety of applicable and useful technologies. During this time, drought disaster management took the form of adaptation measures, and future mitigation efforts are reliant on developing predictions for prevention (Bankoff, Frerks, \& Hilhorst, 2013). These prevention efforts reduced the potential impact of disasters by developing physical structures, increasing awareness, and enhancing the ability to respond to disasters, which are collectively called mitigation (Law No. 24 of 2007). An essential component of disaster mitigation is providing information and maps of disasterprone areas for each type of disaster (Cadag \& Gaillard, 2012). Information and maps of disaster-prone areas are used to predict disasters and reduce the impact and loss caused by the disaster (Poiani, Rocha, Degrossi, \& Albuquerque, 2016). Geographic information systems (GIS) and remote sensing can be used to estimate and mitigate potential drought disasters by incorporating drought-causing parameters into the analysis. Mapping drought potential using remote sensing has proven to be an effective method to get a general picture quickly and accurately (Samarasinghe et al., 2010; Wang \& Qu, 2007; Zhang et al., 2013).

The focus of this research was to determine the drought potential and risk maps for Pacitan Regency's agricultural area using the predicted drought level for 2030 as determined by the business as usual scenario (BAU), regional spatial planning (RSP), and land capability class (LCC). The best drought suppressing land cover for agricultural land in Pacitan Regency, as determined by simulations, was used as an alternative solution. This study analyzed Pacitan Regency's drought potential from 1998 to 2018, projected drought potential to 2030, and provided strategic considerations for minimizing drought disasters by applying LCC and RSPs.

\section{Materials and Method}

\subsection{Research time and location}

The research was conducted from May to November 2019, Pacitan Regency, East Java Province. Pacitan Regency is located at the southwestern tip of East Java Province (coordinates $7^{\circ} 55^{\prime}-8^{\circ} 17^{\prime} \mathrm{S}, 110^{\circ} 55^{\prime}-111^{\circ} 25^{\prime} \mathrm{E}$ ). The oldest rocks that make up the southern mountain range of East Java are Pre-Tertiary metamorphic rocks and Eocene sedimentary rocks derived from Eocene diorite rocks. The Wonosari formation is the largest karst area $(29,987.54 \mathrm{ha})$ and is a drought hazard area (Samodra, Gafoer, \& Tjokrosapoetro, 1992).

Based on the topography model (built using Digital Elevation Model, $8 \mathrm{~m}$ resolution), natural landforms in Pacitan Regency include coastal areas, plains, hills, and mountainous areas with flat to undulating relief. The $25-40 \%$ land slope classification dominated the study area (42,160 ha), followed by $15-25 \%$ slope (31,524 ha), $40-60 \%$ slope ( 29,355 ha), with the remainder being flat, gentle, slightly sloping, or very steep.

Pacitan Regency experiences the same climate as other regions in Java, namely a tropical climate with two seasons (monsoon and dry). Based on Pacitan Regency's rainfall records (BPS-Kabupaten Pacitan, 2018), annual rainfall varies from 1,500 to $2,500 \mathrm{~mm}$ and temperatures range from $18.98^{\circ} \mathrm{C}-26.91^{\circ} \mathrm{C}$.

\subsection{Tools and materials}

The tools and materials used in this study encompass both primary and post-survey activities. Map-making tools used in creating survey sub-district location maps included stationery, a set of computers, and ArcGIS 10.1 and $\mathrm{PCl}$ Geomatica software. A GPS unit, soil survey tools, a camera, and an observation form were used in the soil sampling process. Supporting materials included Indonesian landscape maps (RBI), digital elevation model (DEM) maps, climate data, landform, and geological data, minimum water use and discharge data, and watershed data.

\subsection{Research Stages}

The research was divided into several stages: pre-survey, preliminary survey, primary survey, and post-survey. Presurvey activities consisted of tools and material preparation, obtaining a research permit for the research site, and processing the supporting materials to compile a survey map and determine soil sampling locations. Sample sites were ground-checked in the preliminary survey and then intact and disturbed soils were sampled in the primary survey. Postsurvey activities consisted of data validation and soil sample analysis. The stages of the study are presented in Figure 1.

The research commenced with preparing tools and materials, particularly supplementary information such as water demand data (BPS-Kabupaten Pacitan, 2018), geological maps (Samodra et al., 1992), Climatology data (annual rainfall, dry season duration, evapotranspiration estimates, Q min debits), RSPs, Land Capability Maps and Landsat imagery from 1998, 2008, and 2018.

The first preprocessing step was to make radiometric corrections to the Landsat imagery to improve image quality, eliminate noise, and determine the portion of the image that will be examined by $\mathrm{PCl}$ Geomatica. Then, Haze Cloud Removal was applied to remove the fog or dust contained in the satellite imagery. The land-use classification at different timescales was carried out using $30 \mathrm{~m} \times 30 \mathrm{~m}$ resolution Landsat imagery. Landsat image land-use analysis was performed to classify different land-uses: natural forests, agroforestry, drylands, settlements, water bodies, and other land-uses. The land-use analysis utilized 1998 Landsat 5 TM, 2008 Landsat 7 ETM, and 2018 Landsat 8 OLI imagery. Due to the relatively long period of coverage (10 years), identical Landsat imagery was not obtainable. The unsupervised classification method was used to process Landsat imagery.

Image analyses from three different years were used to determine 2030 BAU land use by linear regression. To compare drought solutions and strategize, ArcGIS 10.3 was used to convert the RSPs and LCCs according to land-use class at BAU. Features on the land-use map (created from 1998, 
2008, 2018 Landsat Imagery, BAU, RSPs, and LCCs) were then weighted and scored, including water demand, geology, dry season, rainfall, evapotranspiration, and $Q$ min. A weighted analysis was used to create the drought map as described in Figure 2.

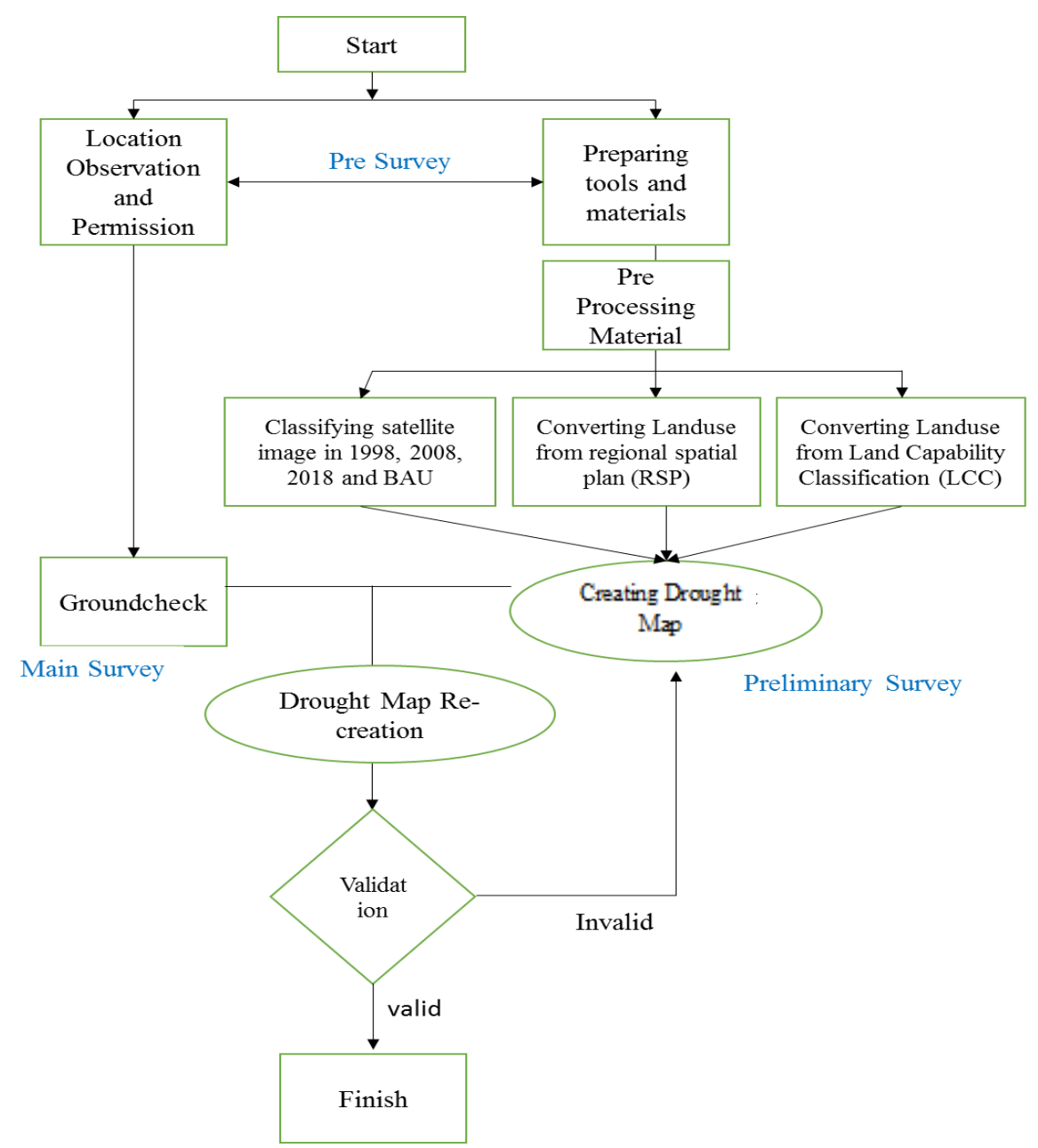

Figure 1. Research stages

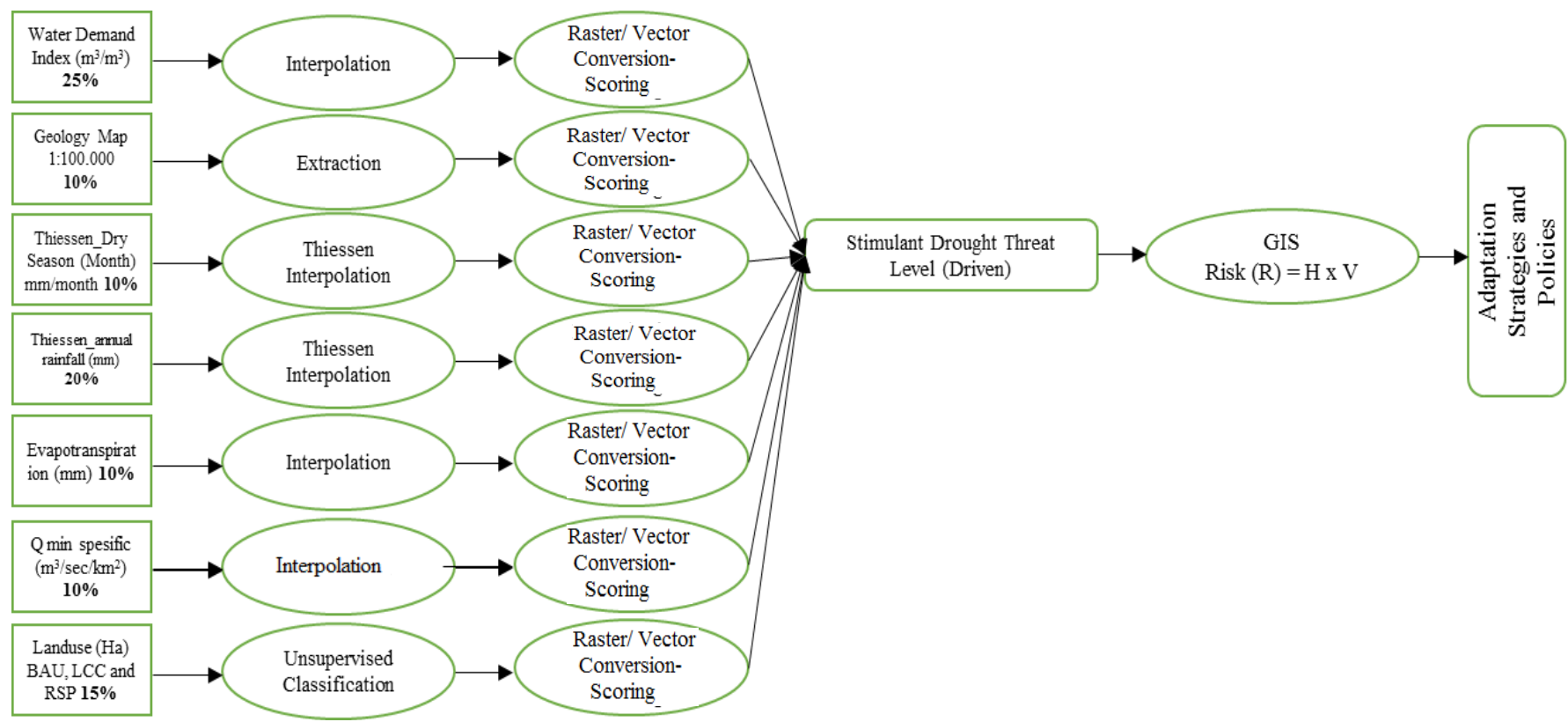

Figure 2. Analysis of drought hazard, model modified from Paimin, Pramono, Purwanto, \& Indrawati (2012)

The model followed in this study was modified from the model described in (Paimin et al., 2012). Remote sensing data processing and GIS analysis were performed using ArcGIS 10.3. Features were scored and weighed using the value 
categories described in (Paimin et al., 2012). The arithmetic overlay for drought potential was calculated using a weighted overlay and predetermined weights.

This research relied on weighted overlay using parameters with predetermined scores so that the final stage could be analyzed using Algebra Map. The results of the analysis were then validated by correlating the results with known situations and ground-checks. During validation, additional observations and data were collected, such as slope, erosion sensitivity and level, depth of soil, rocks, vegetation, and others. The results of the field check were used to compile the drought map, which was then validated by calculating an overall accuracy via a confusion matrix.

\section{Results}

\subsection{Analysis of land-use change and business as usual analysis}

Changes in land use from 1998-2030 varied. Natural forested areas, bushlands, drylands, and settlements increased, while agroforestry areas, coastal regions, and paddy fields decreased (Figure 3). In contrast to natural forests, agroforestry experienced a significant decrease, from 44,749 ha in 1998 to 39,793 ha in 2018 . The extrapolated pattern of decline reduced agroforestry to 36,444 ha in 2030. Other land-uses that predicted to continue their positive growth trend to 2030 are settlements $(6,823$ ha in 2030), bushlands (42,540 ha), and drylands (7,928 ha). Paddy fields and coastal areas were also negatively affected, with predictions of 22,770 ha and 64 ha, respectively.

The decrease in paddy field area was followed by an increase in drylands both in 2008, 2018, and 2030 predictions. This change was assumed to be influenced by land management and plant species selection. The reduction in paddy fields could be a function of housing, given the close proximity of the paddy fields to the district center, public facilities, and centralized offices and suitable topography for residential areas. The existence of paddy fields, drylands, and settlements are likely to also be negatively affected by drought given their close proximity to the more heavily drought-affected areas south of Pacitan Regency. The paddy fields, drylands, and settlements are very close to the Grindulu River, the main river in Pacitan Regency, and are therefore directly connected to the sea.

\subsection{Analysis of land-use according to regional spatial planning}

Pacitan Regency's land use distribution is presented in Table 1. Pacitan Regency is included in RSP until 2028. Land uses listed in the RSP (Table 1) were adjusted to be consistent with land-uses described in BAU and LCC. The Pacitan Regency spatial plan consists of protected and cultivated areas. Land allotment in Pacitan Regency was based on the planned development of protected areas (protected forests, karsts, border areas, areas around springs and high voltage airways, nature and cultural reserves, areas prone to natural disasters, and other protected areas) and cultivated areas (production forests, community forests, agriculture, fisheries, mining, industry, tourism, settlements, mainstays, and areas reserved for the Iswahyudi Air Force airbase). Land-use plans in Pacitan Regency until 2028 will be mostly designated as community forests. These are because Pacitan Regency has a diverse community forest area. The second-largest land-use is cultivated land, which encompasses green open space, agriculture, and settlements.

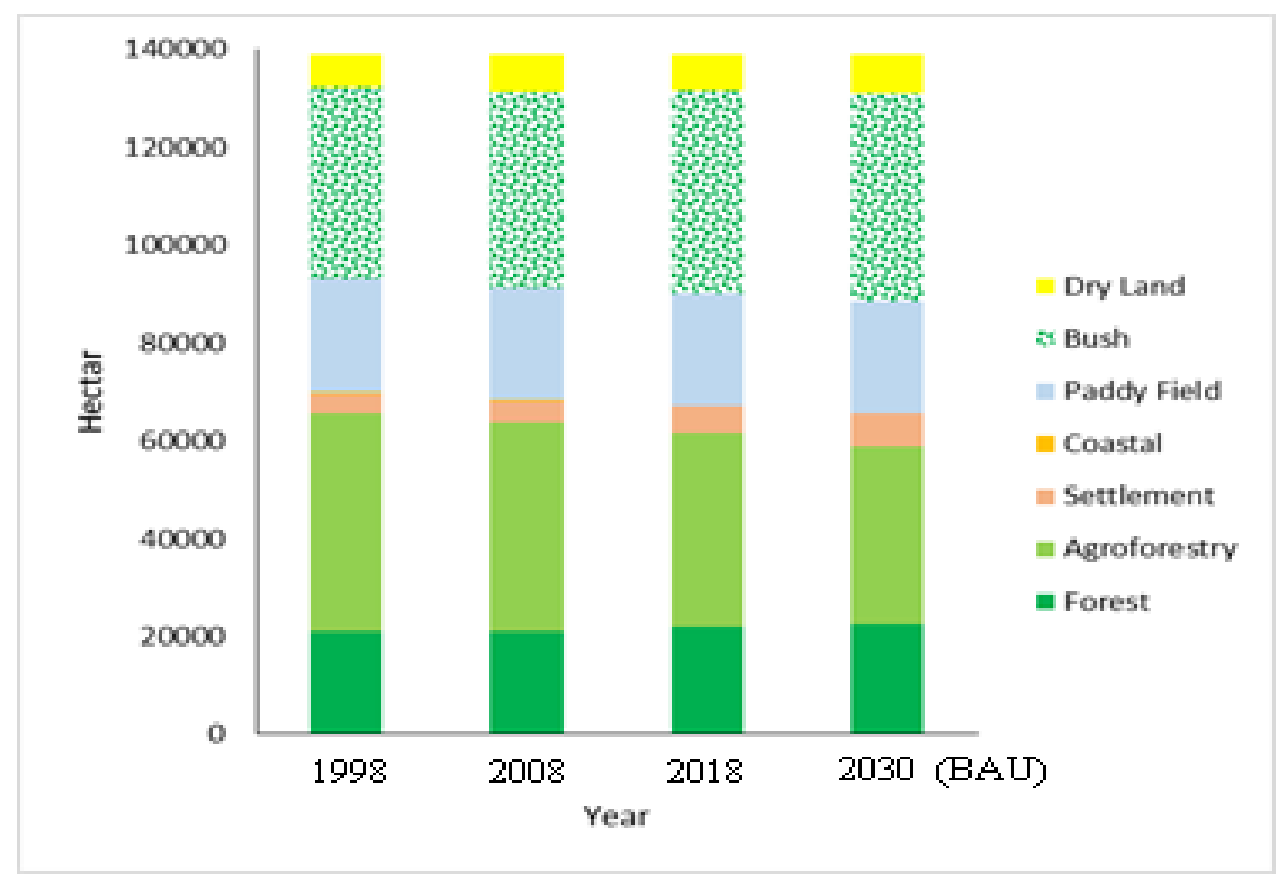

Figure 3. Chart of land-use change in Pacitan Regency 
Table 1. Regional spatial planning Pacitan Regency and its conversion

\begin{tabular}{lrl}
\hline Land-use planning & Area (ha) & Conversion land-use type \\
\hline Public forest area & $65,951.00$ & Primary forest \\
Nature reserves / cultural reserves & $1,254.13$ & Primary forest, production forests, and agroforestry \\
Production forest & $1,484.39$ & Production forest and agroforestry \\
Agriculture & $13,033.00$ & Paddy fields and drylands \\
Settlement & $16,253.31$ & Settlement \\
Green open space/reserve land & $26,720.37$ & Settlements and agroforestry \\
Other & $14,291.00$ & Various kinds of land-use \\
\hline
\end{tabular}

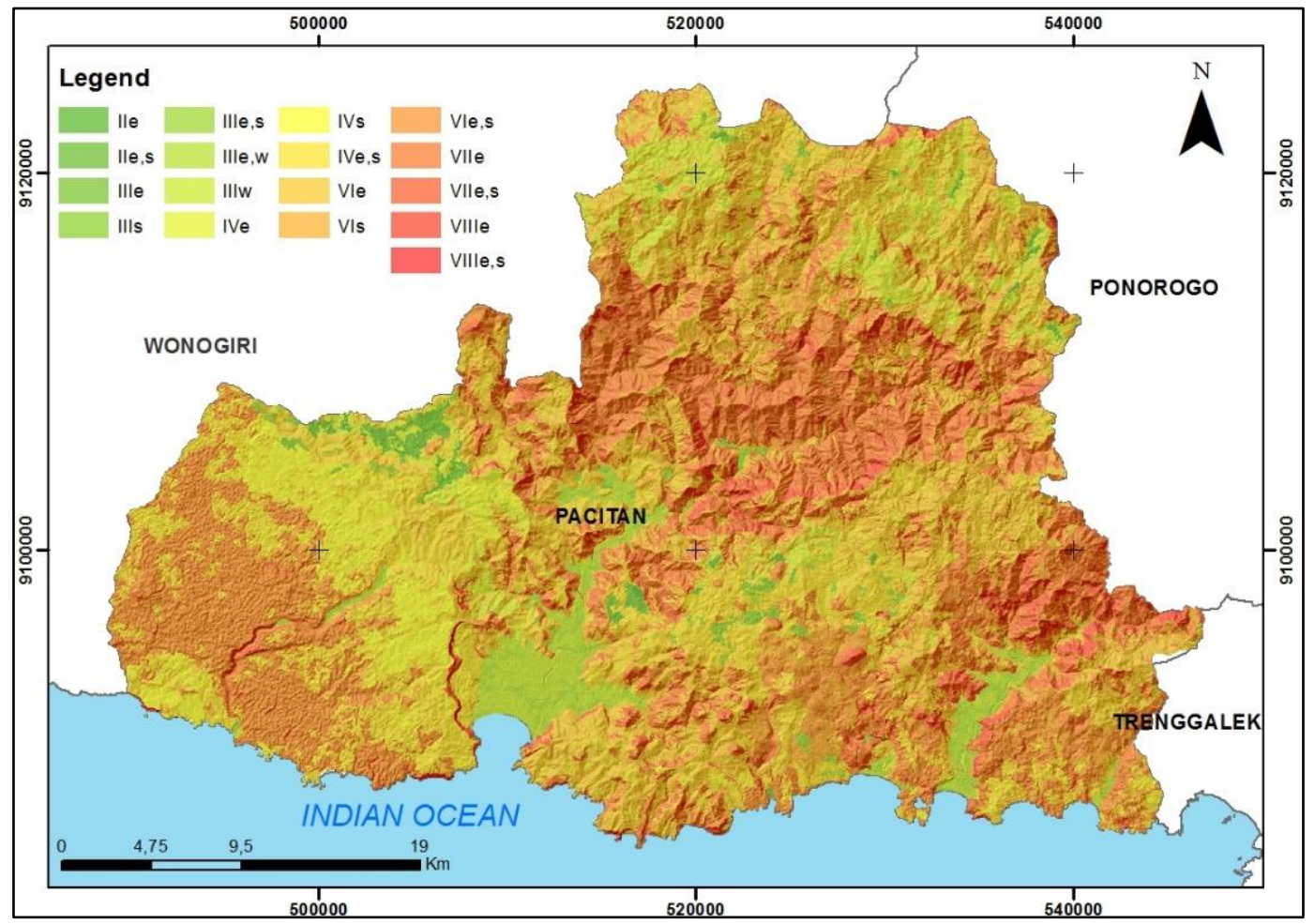

Figure 4. Map of Pacitan Regency land capability

\subsection{Land-use analysis according to carrying capacity (LCC)}

Land capability classification in Pacitan Regency is based on a systematic evaluation of land components that takes into account positive and negative land-use characteristics (Arsyad et al., 1992). Land characteristics assessed are slope, erosion, solum depth, soil texture (both upper and lower layers), permeability, drainage, drought hazard, and salinity. The results of the land capability class analysis are presented in Figure 4. A land-use map based on land carrying capacity, as converted from LCC, is presented in Figure 5, and the respective land-use areas are shown in Table 2.

Table 2. Pacitan Regency land-use types and their respective areas as determined by land capability class

\begin{tabular}{lr}
\hline Land-use types & Area (ha) \\
\hline Forest (Natural and Production) & $93,649.10$ \\
Agroforestry & $1,909.35$ \\
Settlement & $5,856.06$ \\
Paddy field & $6,805.09$ \\
Bush & $2,061.13$ \\
Drylands & $28,709.27$ \\
Coastal & 0.00 \\
\hline
\end{tabular}

Total area (ha)

\subsection{Potential drought hazard}

Land-use changes in 1998, 2008, 2018, 2030 (BAU), RSP, and LCC showed that land use can affect drought hazard potential. Land-use changes can cause high to very-high increases in drought potential. Changes in land use affect land surface conditions, which then affect surface runoff and soil absorption rates. Land use can also affect the shelf life of water in the soil. Future land-use predictions were based on patterns that were observed in previous years' land-use changes, otherwise known as BAU. The results of BAU analysis show that, with no intervention in the current land-use change pattern in Pacitan District, potential drought will increase from very low to low and high to moderate in 2030 (Table 3). Drought-hazard classes in (Paimin et al., 2012) were divided into five classes, however, in Pacitan the very-low class was omitted and only four classes are used.

If the Pacitan Regency Spatial Plan interventions are implemented, the moderate drought potential class as determined by the 2030 BAU may be reduced. However, the moderate to very high classes may increase (Table 3). Landuse planning based on RSPs increases the potential for drought as compared to BAU. This is because RSP land use is 
determined using the LCC. Figure 6 depicts the pattern of potential drought changes from 1998 to 2018 and predictions for 2030 based on BAU, RSP, and LCC. The results of the accuracy assessment of the drought map in Pacitan in 2018 showed a reasonable accuracy rate (75\%) (Figure 7). Of the 100 validation points spread across Pacitan District, 75 of the ground-checks agreed with the calculated results.

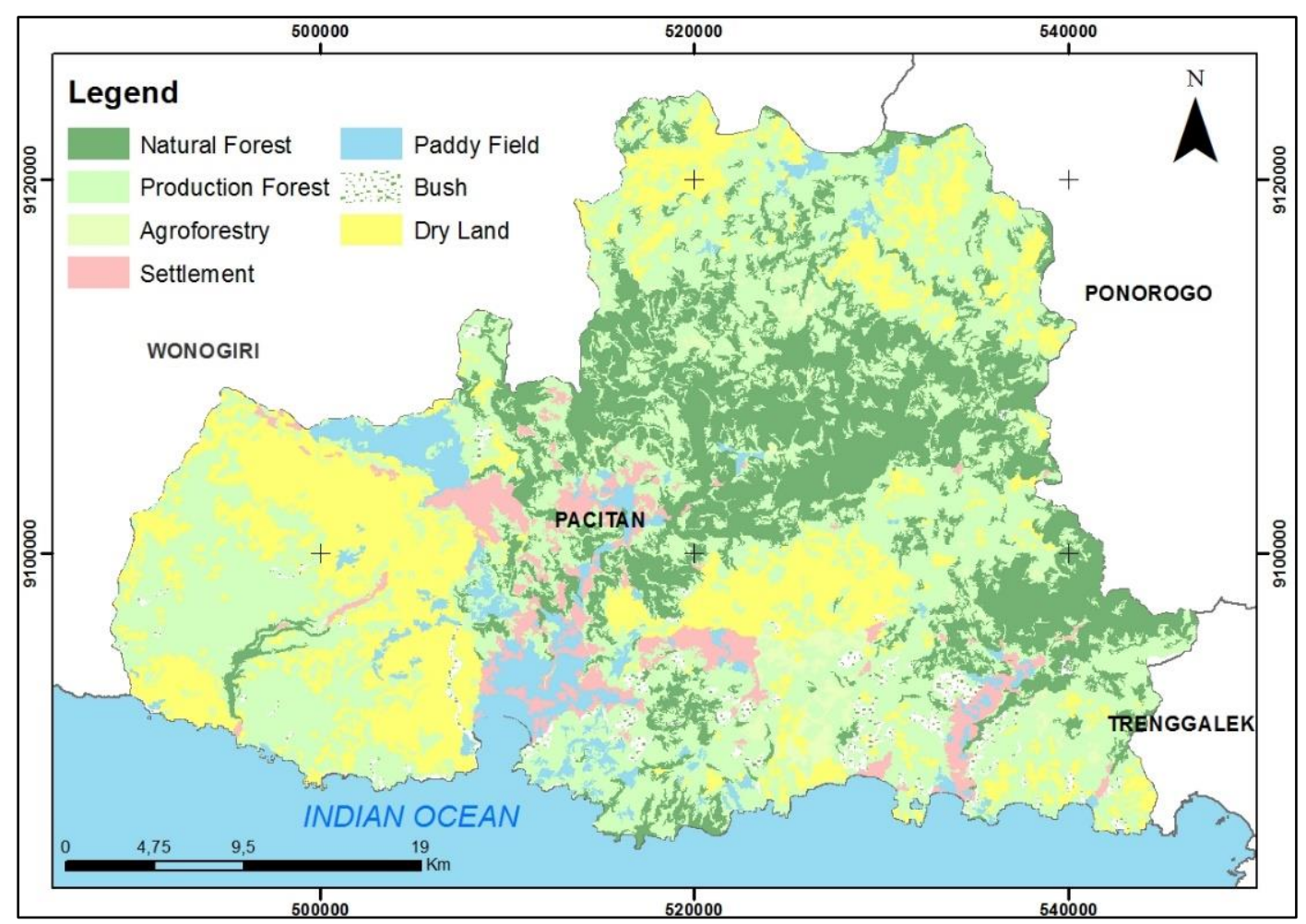

Figure 5. Land-use map based on land capability (as converted from LCC)

Table 3. Results of drought hazard analysis in Pacitan District

\begin{tabular}{|c|c|c|c|c|c|c|}
\hline \multirow{2}{*}{ Drought Potential } & \multicolumn{6}{|c|}{ Area (ha) } \\
\hline & 1998 & 2008 & 2018 & 2030 (BAU) & LCC & RSP \\
\hline Very-Low & 804 & 689 & 999 & 1,046 & 1,813 & 558 \\
\hline Low & 103,186 & 103,317 & 102,917 & 102,803 & 101,152 & 102,931 \\
\hline Moderate & 31,973 & 31,956 & 32,309 & 32,490 & 35,881 & 35,214 \\
\hline High & 3,038 & 3,038 & 2,775 & 2,661 & 154 & 297 \\
\hline Total Area (ha) & \multicolumn{6}{|c|}{138,990} \\
\hline
\end{tabular}

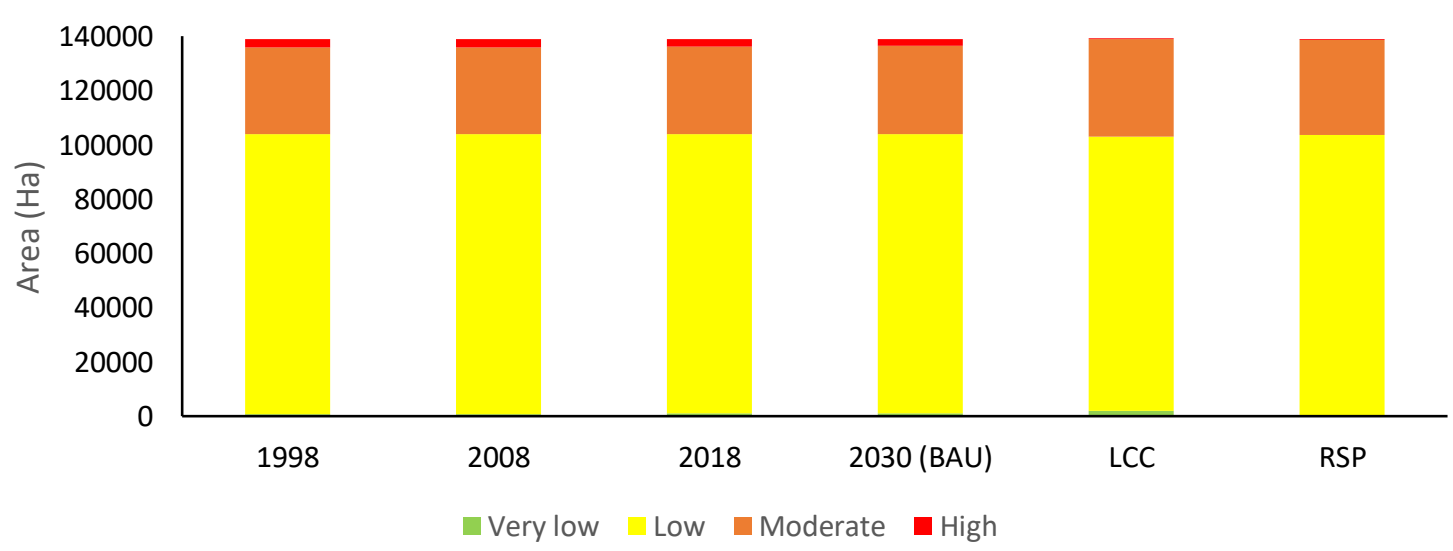

Figure 6. The pattern of potential drought hazards in Pacitan Regency 


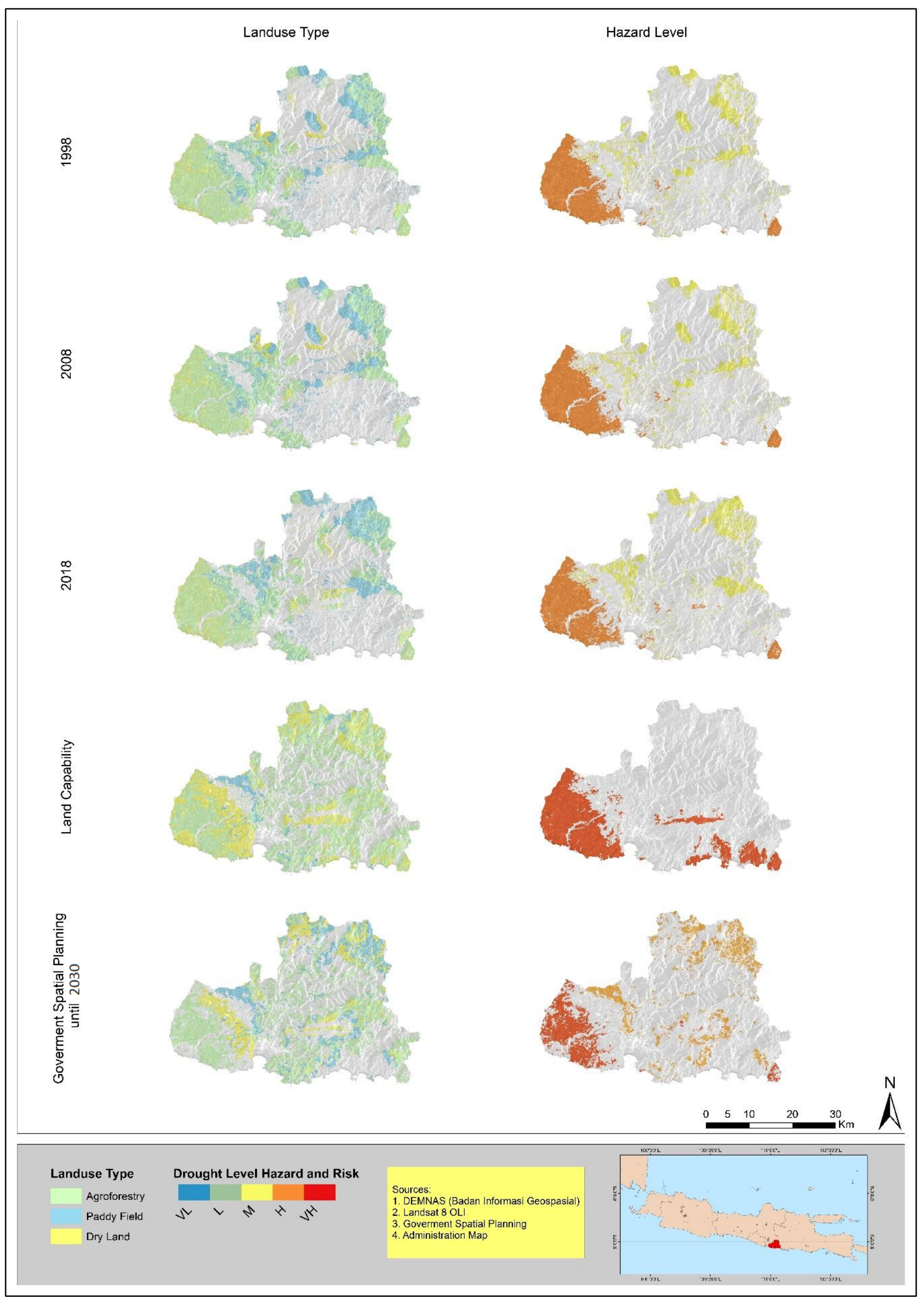

Figure 7. Map of potential drought hazards in Pacitan Regency 


\section{Discussion}

The danger of drought in Pacitan Regency changes over time with insignificant changes. Overall, the drought hazard decreased from 1998 to 2018 and was predicted to be low in 2030 (BAU). These changes to drought danger may be caused by seemingly insignificant land-use changes. Huang, Huang, Chang, \& Leng (2016) argued that drought could be caused by natural conditions, the influence of human activities, and land-use changes. The increase in forest area decreases the drought potential in Pacitan Regency. This phenomenon counterweights the positive correlation between settlements and drought increase. The impact land-use change on drought hazard and hydrological variables varies with the season. It is most observant during the spring and summer seasons when crops take-up more water from the soil and lose more water to the air by evapotranspiration, which leads to a soilmoisture deficit and decreased streamflow and groundwater. During the high spring rains, the ground cover and land-use type play a significant role in runoff, streamflow, and groundwater recharge (Afzal \& Ragab, 2019).

The drought analysis shows an increase in the very low to low drought-hazard class. These need to be addressed before future improvements can occur. The continued drought hazard in Pacitan Regency is a threat to agriculture. In 2018, the damage potential due to drought in Pacitan Regency, particularly to agroforestry land, paddy fields, and dry lands, reached 70,331 ha. Agricultural losses in paddy fields and dry lands in Pacitan Regency are shown in Table 4.

Table 4. Agricultural losses due to drought in Pacitan Regency

\begin{tabular}{|c|c|c|c|c|}
\hline \multirow{2}{*}{ Land-use } & \multicolumn{4}{|c|}{ Danger of Drought } \\
\hline & 1998 & 2008 & 2018 & Area (ha) \\
\hline \multirow{5}{*}{ Agroforestry } & $\mathrm{L}$ & $\mathrm{L}$ & $\mathrm{L}$ & 21,758 \\
\hline & \multirow{2}{*}{ M } & \multirow{2}{*}{$M$} & $\mathrm{~L}$ & 341 \\
\hline & & & $M$ & 16,585 \\
\hline & $\mathrm{VL}$ & $\mathrm{VL}$ & $\mathrm{L}$ & 19 \\
\hline & $\mathrm{H}$ & $\mathrm{H}$ & $M$ & 1,056 \\
\hline \multirow{7}{*}{ Paddy field } & $\mathrm{L}$ & $\mathrm{L}$ & $\mathrm{L}$ & 20,059 \\
\hline & \multirow{3}{*}{ M } & \multirow{3}{*}{ M } & $\mathrm{L}$ & 332 \\
\hline & & & $M$ & 961 \\
\hline & & & $\mathrm{H}$ & 301 \\
\hline & VL & VL & $\mathrm{L}$ & 429 \\
\hline & \multirow{2}{*}{$\mathrm{H}$} & \multirow{2}{*}{$\mathrm{H}$} & $M$ & 88 \\
\hline & & & $\mathrm{H}$ & 797 \\
\hline \multirow{6}{*}{ Dry Land } & $L$ & $L$ & $\mathrm{~L}$ & 3,061 \\
\hline & \multirow{3}{*}{ M } & \multirow{3}{*}{$\mathrm{M}$} & $\mathrm{L}$ & 75 \\
\hline & & & $\mathrm{M}$ & 4,039 \\
\hline & & & $\mathrm{H}$ & 70 \\
\hline & \multirow[t]{2}{*}{$\mathrm{VL}$} & \multirow[t]{2}{*}{$\mathrm{VL}$} & $\mathrm{L}$ & 13 \\
\hline & & & $\mathrm{H}$ & 348 \\
\hline & tal Are & ha) & & 70,331 \\
\hline
\end{tabular}

Notes: H: High; M: Moderate; L: Low; VL: Very Low

In Table 4, the pink-highlighted fields indicate the location of agricultural land that needs to be immediately conserved so that there will be no increase in future drought potential. Adequate soil moisture in agricultural activities is needed to guarantee crop growth and development (Shao et al., 2009). The land was divided into about 429 hectares of paddy fields and 13 hectares of moor. The red-highlighted fields indicate a need for immediate intervention because the drought potential is already very high and could reduce the production of cultivated plants. This concurs with a previous study that concluded that environmental stress triggers a wide variety of plant responses, including plant growth and productivity. Among the environmental stresses, drought is one of the most adverse factors to plant growth and productivity (Reddy, Chaitanya, \& Vivekanandan, 2004; Zhou \& Shao, 2008). The land was separated into 1098 ha of paddy fields and 418 ha of dry land. The potential for drought could be minimized in Pacitan Regency through land-use management. Land-use management has been used as a droughtmanagement technique by various countries in the world, including Sudan. There is a clear need for proper land-use plans that address the needs of all land users and reduce the effects of drought (Bazza, Kay, \& Knutson, 2018).

\section{Conclusion}

Based on the research that had been done, the potential for increased drought risk in Pacitan Regency is at medium and high levels. The increase of drought potential occurred due to changes in land-use, particularly on paddy fields and dry land. Based on the results of the BAU analysis, the 2030 drought risk potential will increase. Drought potential will increase from high-risk areas will increase to very high levels if there is no improvement in spatial planning. Improvements are needed in spatial planning to reduce the risk of drought.

\section{Acknowledgments}

Our gratitude goes to the Faculty of Agriculture and the University of Brawijaya for the University of Brawijaya's 2019 Beginner Researcher Grant Funds, which were essential to the orderly and efficient implementation of this research.

\section{Declaration of Competing Interest}

The authors declare no competing financial or personal interests that may appear and influence the work reported in this paper.

\section{References}

Afzal, M., \& Ragab, R. (2019). Drought Risk under Climate and Land Use Changes: Implication to Water Resource Availability at Catchment Scale. Water (Switzerland), 11(9). https://doi.org/10.3390/w11091790

Arsyad, S., \& et al. (1992). Conservation Policies for Sustainable Hillslope Farming. Ankeny, lowa: Soil and Water Conservation Society.

Azadi, H., Keramati, P., Taheri, F., Rafiaani, P., Teklemariam, D., Gebrehiwot, K., ... Witlox, F. (2018). Agricultural Land Conversion: Reviewing Drought Impacts and Coping Strategies. International Journal of Disaster Risk Reduction 31 , 184-195. https://doi.org/10.1016/j.ijdrr.2018.05.003

Bankoff, G., Frerks, G., \& Hilhorst, D. (2013). Mapping Vulnerability: Disasters, Development, and People 
(eBook). London, UK: Routledge. https://doi.org/10.4324/9781849771924

Bazza, M., Kay, M., \& Knutson, C. (2018). Drought Characteristics and Management in North Africa and the Near East. Food and Agriculture Organization of the United Nations: FAO Water Reports. Rome, Italy. Retrieved from http://www.fao.org/3/CA0034EN/ca0034en.pdf

BPS-Kabupaten Pacitan. (2018). Kabupaten Pacitan Dalam Angka 2018. Pacitan, Indonesia: BPS Kabupaten Paacitan. Retrieved from https://pacitankab.bps.go.id/publication/2018/08/16/ bafef806e5ca9623df129726/kabupaten-pacitandalam-angka-2018.html

Cadag, J. R. D., \& Gaillard, J. (2012). Integrating Knowledge and Actions in Disaster Risk Reduction: The Contribution of Participatory Mapping. Area, 44(1), 100-109. https://doi.org/10.1111/j.14754762.2011.01065.x

D’Arrigo, R., \& Wilson, R. (2008). El Nino and Indian Ocean Influences on Indonesian Drought: Implications for Forecasting Rainfall and Crop Productivity. International Journal of Climatology, 28(5), 611-616. https://doi.org/10.1002/joc.1654

Hamidi, H., \& Safarnejad, A. (2010). Effect of Drought Stress on Alfalfa Cultivars (Medicago sativa L.) in Germination Stage. American-Eurasian Journal of Agricultural \& Environmental Sciences, 8(6), 705-709. https://doi.org/10.1007/s12355-014-0337-y

Huang, S., Huang, Q., Chang, J., \& Leng, G. (2016). Linkages between Hydrological Drought, Climate Indices, and Human Activities: A Case Study in the Columbia River Basin. International Journal of Climatology, 36(1), 280290. https://doi.org/10.1002/joc.4344

Paimin, Pramono, I. B., Purwanto, \& Indrawati, D. R. (2012). Sistem Perencanaan Pengelolaan Daerah Aliran Sungai. Kementerian Kehutanan, Badan Penelitian dan Pengembangan Kehutanan, Pusat Penelitian dan Pengembangan Konservasi dan Rehabilitasi. Bogor, Indonesia: Pusat Penelitian dan Pengembangan Konservasi dan Rehabilitasi.

Poiani, T. H., Rocha, R. D. S., Degrossi, L. C., \& Albuquerque, J. P. D. (2016). Potential of Collaborative Mapping for Disaster Relief: A Case Study of OpenStreetMap in the Nepal Earthquake 2015. In 2016 49th Hawaii International Conference on System Sciences (HICSS) (pp. 188-197). Hawai: IEEE. https://doi.org/10.1109/HICSS.2016.31

Reddy, A. R., Chaitanya, K. V., \& Vivekanandan, M. (2004). Drought-Induced Responses of Photosynthesis and antioxidant Metabolism in Higher Plants. Journal of Plant Physiology, 161(11), 1189-1202. https://doi.org/10.1016/j.jplph.2004.01.013

Samarasinghe, S. M. J. S., Nandalal, H. K., Weliwitiya, D. P., Fowze, J. S. M., Hazarika, M. K., \& Samarakoon, L. (2010). Application of Remote Sensing and GIS for Flood Risk Analysis: A Case Study at Kalu-Ganga River, Sri Lanka. International Archives of the Photogrammetry, Remote Sensing and Spatial Information Science, 38(8), 110-115.

Samodra, H., Gafoer, S., \& Tjokrosapoetro, S. (1992). Peta Geologi Lembar Pacitan, Jawa, skala 1: 100.000. Bandung. Indonesia: Pusat Penelitian dan Pengembangan Geologi.

Shao, H. B., Chu, L. Y., Jaleel, C. A., Manivannan, P., Panneerselvam, R., \& Shao, M. A. (2009). Understanding Water Deficit Stress-Induced Changes in the Basic Metabolism of Higher Plants Biotechnologically and Sustainably Improving Agriculture and the Ecoenvironment in Arid Regions of the Globe. Critical Reviews in Biotechnology, 29(2), 131-151.

https://doi.org/10.1080/07388550902869792

Venuprasad, R., Lafitte, H. R., \& Atlin, G. (2007). Response to Direct Selection for Grain Yield under Drought Stress in Rice. Crop Science, 47(1), 285-293. https://doi.org/10.2135/cropsci2006.03.0181

Wang, L., \& Qu, J. J. (2007). NMDI: A Normalized Multi-Band Drought Index for Monitoring Soil and Vegetation Moisture with Satellite Remote Sensing. Geophysical Research Letters, 34(20). https://doi.org/10.1029/2007GL031021

Zhang, F. J., Zhang, K. K., Du, C. Z., Li, J., Xing, Y. X., Yang, L. T., \& Li, Y. (2015). Effect of Drought Stress on Anatomical Structure and Chloroplast Ultrastructure in Leaves of Sugarcane. Sugar Tech, 17(1), 41-48. https://doi.org/10.1007/s12355-014-0337-y

Zhang, Y., Peng, C., Li, W., Fang, X., Zhang, T., Zhu, Q., ... Zhao, P. (2013). Monitoring and Estimating Drought-Induced Impacts on Forest Structure, Growth, Function, and Ecosystem Services Using Remote-Sensing Data: Recent Progress and Future Challenges. Environmental Reviews, 21(2), 103-115. https://doi.org/10.1139/er2013-0006

Zhou, Y., \& Shao, H. (2008). The Responding Relationship between Plants and Environment is the Essential Principle for Agricultural Sustainable Development on the Globe. Comptes Rendus Biologies, 331(4), 321-328. https://doi.org/10.1016/j.crvi.2008.01.008 